\title{
RESULTS OF KYPHOPLASTY IN THE MINIMALLY INVASIVE TREATMENT OF VERTEBRAL METASTASIS
}

\author{
RESULTADO DA CIFOPLASTIA NO TRATAMENTO MINIMAMENTE INVASIVO DAS \\ METÁSTASES VERTEBRAIS
}

\section{RESULTADO DE LA CIFOPLASTIA EN EL TRATAMIENTO MÍNIMAMENTE INVASIVO DE LAS METÁSTASIS VERTEBRALES}

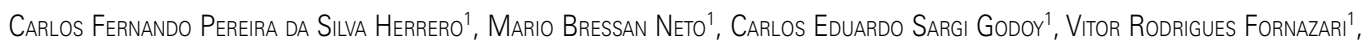
Lilian Maria Pacola ${ }^{1}$, Marcello Henrique Nogueira-Barbosa', Helton Luiz Aparecido Defino ${ }^{1}$

\begin{abstract}
Objective: To evaluate the clinical and radiological outcome of minimally invasive surgical treatment of vertebral metastases using the technique of kyphoplasty. Methods: This was a prospective observational study of patients with the diagnosis of spinal metastasis who underwent minimally invasive surgical treatment by filling the vertebral body with balloon kyphoplasty technique. Clinical evaluation included patient age at surgery, diagnosis of the tumor, biopsy results, data of the surgical procedure performed, visual pain scale (VAS) and complications related to surgery. Radiological evaluation involved the study of radiographic procedures in the anteroposterior and lateral incidences, with the analysis of vertebral body kyphosis and the occurrence of extravasation of cement. Results: 22 patients with spinal metastases who were treated by balloon kyphoplasty, 8 (36\%) males and 14 (64\%) females were studied. The average age was 56.05 years and the mean follow-up was 8.5 months. The mean preoperative VAS was $8.73,1.73$ in the initial postoperative period, and 1.92 in the late postoperative period. Conclusion: Kyphoplasty proved to be a safe and effective technique for symptomatic treatment of vertebral metastases.
\end{abstract}

Keywords: Kyphoplasty; Neoplasm metastasis; Spine; Minimally invasive surgical procedures; Spinal fractures; Spinal neoplasms.

\section{RESUMO}

Objetivo: Avaliar o resultado clínico e radiológico do tratamento cirúrgico minimamente invasivo das metástases vertebrais por meio da técnica de cifoplastia. Métodos: Este é um estudo obsenvacional prospectivo de pacientes com diagnóstico de metástase vertebral, que foram submetidos ao tratamento cirúrgico minimamente invasivo por meio de preenchimento do corpo vertebral com a técnica de cifoplastia com balão. A avaliação clínica incluiu a idade do paciente no momento da cirurgia, o diagnóstico do tumor, os resultados das biópsias, os dados do procedimento cirúrgico realizado, a escala visual de dor (EVA) e as complicações relacionadas à cirurgia. A avaliação radiológica envolveu o estudo dos exames radiográficos nas incidências anteroposterior e lateral, com a análise da cifose do corpo vertebral e a ocorrência de extravasamento do cimento. Resultados: Foram estudados 22 pacientes portadores de metástase vertebral que foram tratados por meio de cifoplastia com balão, sendo 8 (36\%) do sexo masculino e 14 (64\%) do sexo feminino. A média de idade foi de 56,05 anos e o tempo médio de seguimento, 8,5 meses. A média da EVA pré-operatória foi de 8,73, no pós-operatório inicial, de 1,73 e no pós-operatório tardio, de 1,92. Conclusão: a cifoplastia mostrou-se uma técnica segura e efetiva para o tratamento sintomático das metástases vertebrais.

Descritores: Cifoplastia; Metástase neoplásica; Coluna vertebral; Procedimentos cirúrgicos minimamente invasivos; Fraturas da coluna vertebral; Neoplasias da coluna vertebral.

\section{RESUMEN}

Objetivo: Evaluar el resultado clínico y radiológico del tratamiento quirúrgico mínimamente invasivo de las metástasis vertebrales utilizando la técnica de cifoplastia. Métodos: Se trata de un estudio observacional prospectivo de los pacientes con el diagnóstico de metástasis vertebral que se sometieron a tratamiento quirúrgico mínimamente invasivo mediante el llenado del cuerpo vertebral con la técnica de cifoplastia con balón. La evaluación clínica incluyó la edad del paciente en la cirugía, el diagnóstico del tumor, los resultados de la biopsia, los datos del procedimiento quirúrgico realizado, la escala visual de dolor (EVA) y las complicaciones relacionadas con la cirugía. La evaluación radiológica implicó el estudio de exámenes radiográficos en las incidencias anteroposterior y lateral, con el análisis de la cifosis del cuerpo vertebral y la ocurrencia de la extravasación del cemento. Resultados: 22 pacientes con metástasis vertebrales que fueron tratados con cifoplastia con balón, siendo 8 (36\%) hombres y 14 (64\%) mujeres. La edad promedio fue de 56,05 años y la media de seguimiento fue de 8,5 meses. La media preoperatoria de la EVA fue 8,73, la postoperatoria inicial fue de 1,73 y la postoperatoria tardía fue 1,92. Conclusión: La cifoplastia ha demostrado ser una técnica segura y eficaz para el tratamiento sintomático de las metástasis vertebrales.

Descriptores: Cifoplastia; Metástasis de la neoplasia; Columna vertebral; Procedimientos quirúrgicos mínimamente invasivos; Fracturas de la columna vertebral; Neoplasias de la columna vertebral.

\section{INTRODUCTION}

One characteristic of metastatic disease involving the spine is the presence of fractures of the vertebral bodies affected by the tumor. ${ }^{1,2}$ This complication is a serious health problem because, in addition to affecting a high number of patients, it is responsible for reducing their quality of life and increasing costs for the health care system. ${ }^{1,3-7}$

Balloon kyphoplasty is a minimally invasive procedure that pro-

1. Department of Biomechanics, Medicine, and Rehabilitation of the Faculdade de Medicina de Ribeirão Preto of the Universidade de São Paulo, Ribeirão Preto, SP, Brazil.

Study conducted at the Hospital das Clínicas de Ribeirão Preto of the Universidade de São Paulo, Ribeirão Preto, SP, Brazil.

Correspondence: Helton L. A. Defino. Av dos Bandeirantes, 3900, 11º andar, Ribeirão Preto, São Paulo, SP, Brasil. 14048-900. hladefin@fmrp.usp.br 
motes stabilization of spinal fractures and correction of the kyphotic segmental deformity resulting from the fracture..$^{8,9}$ Its effectiveness in relieving pain, reducing the use of medication, and improving the quality of life is documented in the literature on the treatment of osteoporotic fractures. ${ }^{10-13}$

Few studies have reported the outcomes of balloon kyphoplasty in the treatment of metastatic lesions of the spine..$^{8,14-20}$ Moreover, these studies were usually conducted with heterogeneous groups, including osteoporotic fractures. ${ }^{15,18}$ The objective of this study was to evaluate the results of the treatment of spinal tumor lesions using the balloon kyphoplasty technique.

\section{MATERIAL AND METHODS}

This is an observational study of a prospective database of patients diagnosed with spinal tumor lesions and treated using the balloon kyphoplasty technique. Following approval by the local Research Ethics Committee, the study was conducted via clinical evaluation, radiological evaluation, and review of medical records and radiological archives. All patients with spinal tumor lesions treated with the balloon kyphoplasty technique during the period from August 2010 to January 2014 were included. Patients who underwent kyphoplasty for other diagnoses and patients with spinal tumor lesions who underwent other types of treatment were excluded. All surgical procedures were indicated by the same surgeon, and the criteria adopted were the existence of a spinal tumor lesion and local pain in the topography of the affected vertebra. The clinical history and radiological evaluation were used to establish a diagnosis of fractures secondary to the tumor. The procedure was contraindicated in the presence of neurological deficit or compression of the spinal canal by the tumor lesion. Twenty-two patients aged between 16 and 85 years of age participated in the study: 14 females and 8 males.

The patients were evaluated preoperatively by applying the visual analog pain scale (VAS) to determine pain intensity, where zero indicates "without pain" and 10 indicates "very strong pain". ${ }^{21}$ The type and location of the tumor and duration of symptoms were also evaluated. A radiographic assessment was performed using anteroposterior and lateral $x$-rays, measurement of the angle of vertebral kyphosis (wedging) of the affected vertebrae, ${ }^{22}$ nuclear magnetic resonance of the whole spine to identify other lesions, and computed tomography of the affected region to evaluate the integrity of the posterior cortex. (Figure 1)

The surgical procedure of balloon kyphoplasty was performed under general anesthesia with the aid of a fluoroscope, and the technique used was the same as that described by other authors. ${ }^{8,23,24}$ During the surgical procedure, a biopsy was performed and the
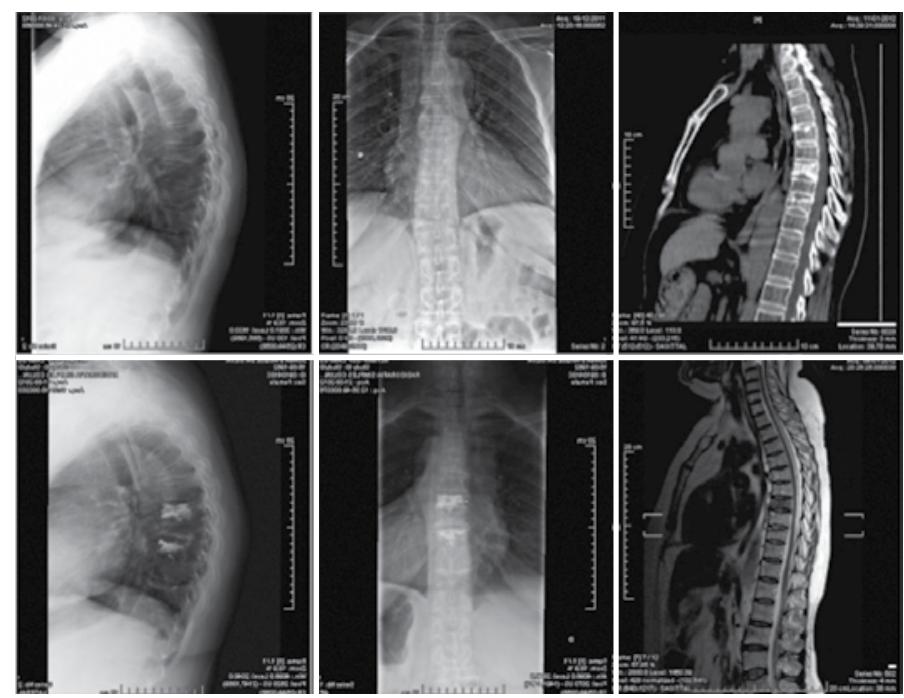

Figure 1. Example of a patient treated using balloon kyphoplasty. material was sent for anatomopathological analysis for a definitive diagnosis of the lesion. During the postoperative period, rigid orthosis was not used and movement and walking were permitted, as far as the pain allowed.

A clinical evaluation and radiographic exams were repeated on the first day after the operation, and subsequent evaluations were conducted at 1 month, 3 months, 6 months, and 1 year following surgery and then annually. During follow-up, pain intensity using the VAS, ${ }^{21}$ clinical complications, radiographic complications, and wedging levels of the affected vertebrae were evaluated. ${ }^{22}$

Continuation of oncological treatment followed the customary protocol recommended by the oncology team in response to the anatomopathological results of the biopsy performed.

The data was evaluated for consistency, codified, and transcribed into a database. A descriptive data analysis was performed using Microsoft Excel $2011^{\circledR}$ and SAS JMP ${ }^{\circledR} 11.0$ software.

\section{RESULTS}

We studied 22 patients with metastases affecting at least one vertebral body who underwent the balloon kyphoplasty surgical procedure. Eight were male (36\%) and 14 were female (64\%), with ages ranging from 16 to 85 years $(56.05 \pm 16.06)$. A total of 35 kyphoplasties were performed, 24 lumbar (67\%), 10 thoracic (29\%), and 1 sacral (3\%). (Figure 2) The tumor types are shown in Figure 3. Patient follow-up ranged from zero to 26 months, with an average of $8.5 \pm 8.46$ months. Of the total number of patients accompanied by the study $(n=22), 4(18 \%)$ died during follow-up from complications of the underlying disease and 2 (9\%) were lost to follow-up. (Table 1)

The VAS ranged from 6 to 10 (average of $8.73 \pm 1.12$ ) in the preoperative period, from zero to 5 (average of $1.73 \pm 1.39$ ) in the immediate postoperative period, and from zero to 8 (average of $1.92 \pm 2.90)$ in the late postoperative period. There was an average

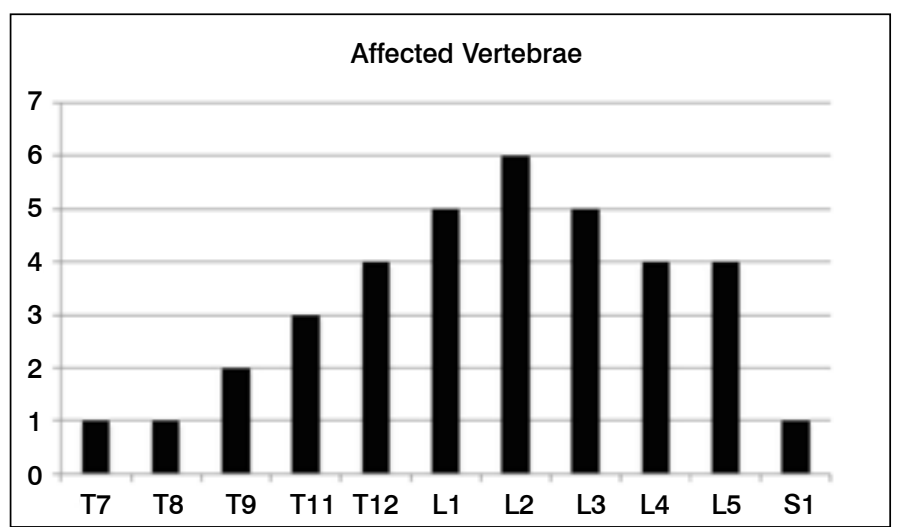

Figure 2. Location of the affected vertebrae.

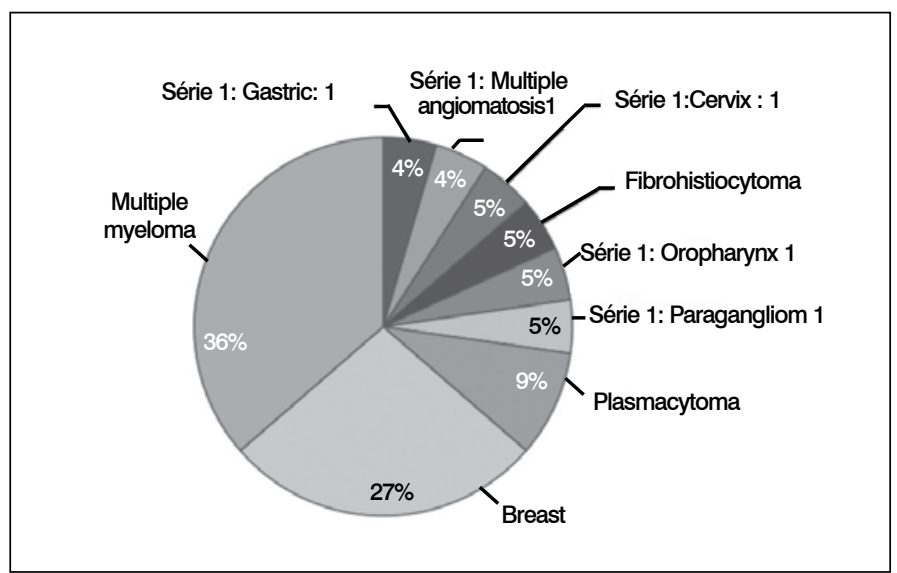

Figure 3. Distribution of tumor types. 
Table 1. Clinical data, scale, visual pain scale (VAS), and complications.

\begin{tabular}{|c|c|c|c|c|c|c|c|c|c|}
\hline Patient & Sex & Age & Diagnostic hypothesis & Location & Follow-up (months) & & VAS & & Complications \\
\hline & & & & & & Pre & Post & Late & \\
\hline 2 & $\mathrm{~F}$ & 73 & Breast adenocarcinoma & L1 & 1 & 9 & 3 & 0 & \\
\hline 4 & $\mathrm{~F}$ & 85 & Breast adenocarcinoma & T8 & 0 & 9 & 1 & 0 & \\
\hline 5 & $\mathrm{~F}$ & 53 & Breast adenocarcinoma & $\mathrm{T} 12 ; \mathrm{L} 1$ & 12 & 8 & 2 & 0 & Death \\
\hline 6 & $\mathrm{~F}$ & 59 & Breast adenocarcinoma & L5 & 0 & 9 & 1 & \begin{tabular}{|l|} 
Death \\
\end{tabular} & Death \\
\hline 9 & $\mathrm{M}$ & 16 & Multiple angiomatosis & T7;T9 & 14 & 7 & 1 & $\mathrm{P}^{*}$ & \\
\hline 10 & $\mathrm{M}$ & 50 & Oropharyngeal adenocarcinoma & L3 & 13 & 9 & 1 & Death & Leakage into the lower disc; Death \\
\hline 11 & $\mathrm{~F}$ & 62 & Fibrous histiocytoma & L5 & 19 & 8 & 3 & 8 & Leakage into the canal \\
\hline 12 & $\mathrm{~F}$ & 63 & Multiple myeloma & L1 & 26 & 10 & 1 & 0 & \\
\hline 13 & $\mathrm{M}$ & 62 & Multiple myeloma & L4 ; L5 & 1 & 10 & 5 & 8 & \\
\hline 14 & $\mathrm{M}$ & 64 & Multiple myeloma & L3 & 2 & 10 & 0 & 0 & \\
\hline 19 & $\mathrm{~F}$ & 67 & Multiple myeloma & $\mathrm{T} 11 ; \mathrm{T} 12$ & 18 & 9 & 2 & 0 & \\
\hline 20 & $\mathrm{M}$ & 24 & Paraganglioma & L4; L5 & 10 & 8 & 2 & 5 & Compression of the canal 2 months following surgery \\
\hline 21 & $\mathrm{~F}$ & 62 & Plasmacytoma & $\mathrm{L} 2$ & 1 & 9 & 0 & $P^{*}$ & \\
\hline 22 & $\mathrm{~F}$ & 62 & Plasmacytoma & $\mathrm{L} 2$ & 25 & 8 & 4 & 0 & Anterior leakage \\
\hline
\end{tabular}

improvement of $7 \pm 1.95$ points in the VAS between the preoperative and immediate postoperative periods. There was no statistical difference in the VAS between the immediate and late postoperative periods. (Figure 4) The measurements of the wedging of the fractured vertebrae are displayed in Table 2. There was no difference between the pre- and postoperative measurements. (Figure 5)

No neurological or cardiac complications were observed. One case of deep vein thrombosis with pulmonary thromboembolism was observed during hospitalization and was successfully treated with anticoagulants. Leakage of cement in 5 vertebrae (14.29\%) was observed during the procedure via fluoroscopic images or postoperatively via radiographs: in 3 cases $(8.6 \%)$ through the anterior cortex of the vertebral body, in one case $(2.9 \%)$ to the disc below, and in one case $(2.9 \%)$ into the spinal canal. The leakage did not cause symptoms in any of the cases. Two patients suffered new fractures during follow-up (9.10\%): one in an adjacent vertebra and the other in a distant vertebra. Both were treated conservatively, by observation only, with resolution of symptoms. During follow-up, one

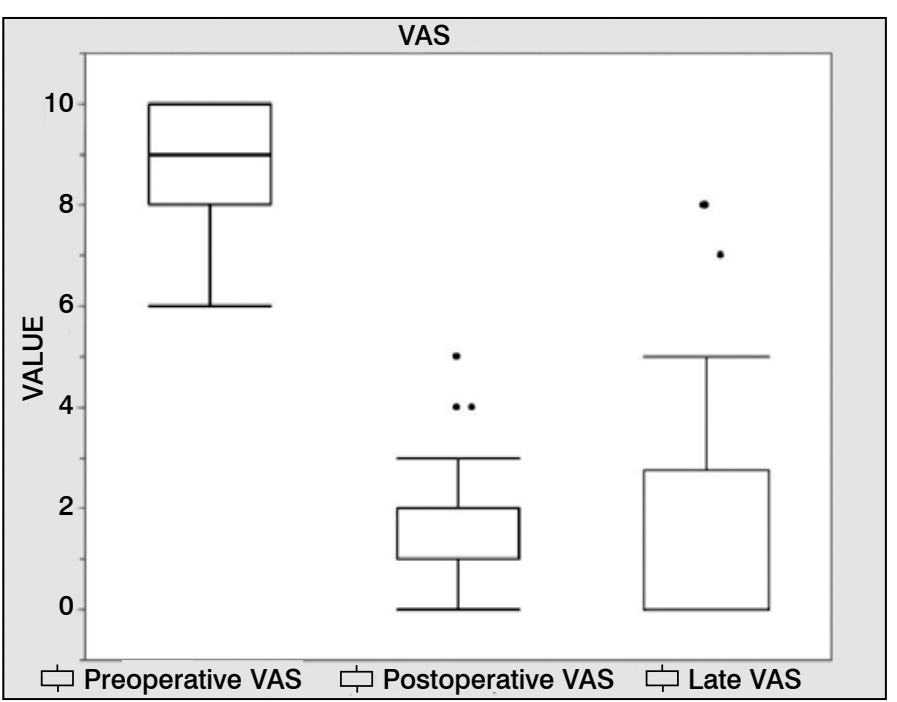

Figure 4. Visual analog pain scale (VAS) during preoperative, immediate postoperative, and late postoperative periods.
Table 2. Measurement of the angle of vertebral kyphosis

\begin{tabular}{c|c|c|c}
\hline \multirow{2}{*}{ Patient } & \multirow{2}{*}{ Location } & \multicolumn{2}{|c}{ Kyphosis } \\
\cline { 3 - 4 } & $\mathrm{L} 2 ; \mathrm{L} 3$ & Preoperative & Postoperative \\
\hline 1 & $\mathrm{~L} 1$ & $6 ; 1$ & $4 ; 0$ \\
\hline 2 & $T 9$ & 74 & 12 \\
\hline 3 & $\mathrm{~T} 8$ & 14 & 8.2 \\
\hline 4 & $\mathrm{~T} 12 ; \mathrm{L} 1$ & $14 ; 1$ & 13 \\
\hline 5 & $\mathrm{~L} 5$ & -4 & -8 \\
\hline 6 & $\mathrm{~L} 1 ; \mathrm{L} 2 ; \mathrm{S} 1$ & $7 ; 9 ; \mathrm{NA}$ & $9 ; 8 ; \mathrm{NA}$ \\
\hline 7 & $\mathrm{~T} 12 ; \mathrm{L} 4$ & unavailable; 8 & $15 ; 4$ \\
\hline 8 & $\mathrm{~T} 7 ; \mathrm{T} 9$ & unavailable & $2 ; 0$ \\
\hline 9 & $\mathrm{~L} 3$ & 12 & 15 \\
\hline 10 & $\mathrm{~L} 5$ & unavailable & -4.7 \\
\hline 11 & $\mathrm{~L} 1$ & 5.5 & 0.7 \\
\hline 12 & $\mathrm{~L} 4 ; \mathrm{L} 5$ & $0 ; 0$ & $2 ; 0$ \\
\hline 13 & $\mathrm{~L} 3$ & 9 & 10 \\
\hline 14 & $\mathrm{~L} 3$ & 0 & 0 \\
\hline 15 & $T 11 ; \mathrm{L} 2$ & $5 ; 19$ & $3 ; 13$ \\
\hline 16 & $\mathrm{~L} 2 ; \mathrm{L} 3 ; \mathrm{L} 4$ & $5 ; 4 ; 6$ & $9 ; 8 ; 6$ \\
\hline 17 & $\mathrm{~T} 12 ; \mathrm{L} 1$ & $15 ; 9$ & $14 ; 23$ \\
\hline 18 & $\mathrm{~T} 11 ; T 12$ & $14 ; 25$ & $7 ; 23$ \\
\hline 19 & $\mathrm{~L} 4 ; \mathrm{L} 5$ & 4 & 3 \\
\hline 20 & $\mathrm{~L} 2$ & 14 & 15 \\
\hline 21 & & 4 & 8.8 \\
\hline 22 & & \multicolumn{3}{|c}{}
\end{tabular}

patient (4.55\%) experienced medullar compression at the level of the pathological fracture caused by tumor growth and underwent radiotherapy, with favorable evolution. (Table 1)

\section{DISCUSSION}

Morbidity and mortality rates are high in patients with spinal involvement from metastatic disease, and because of improvements in oncological treatment, quality of life has become an extremely important and much studied issue. . $^{1,24}$ Balloon kyphoplasty is a minimally invasive procedure capable of stabilizing spinal fractures and reducing pain intensity while improving function and consequently, the quality of life. ${ }^{10,12,13,23,24}$ However, the mechanism responsible for alleviating the pain is controversial, as it can be attributed either to stabilization or to thermal injury of the nerve endings. ${ }^{23,25,26}$

This study demonstrated short- and long-term pain relief resulting from treatment by means of kyphoplasty of the metastatic lesions of the vertebral body, agreeing with previous reports in the 


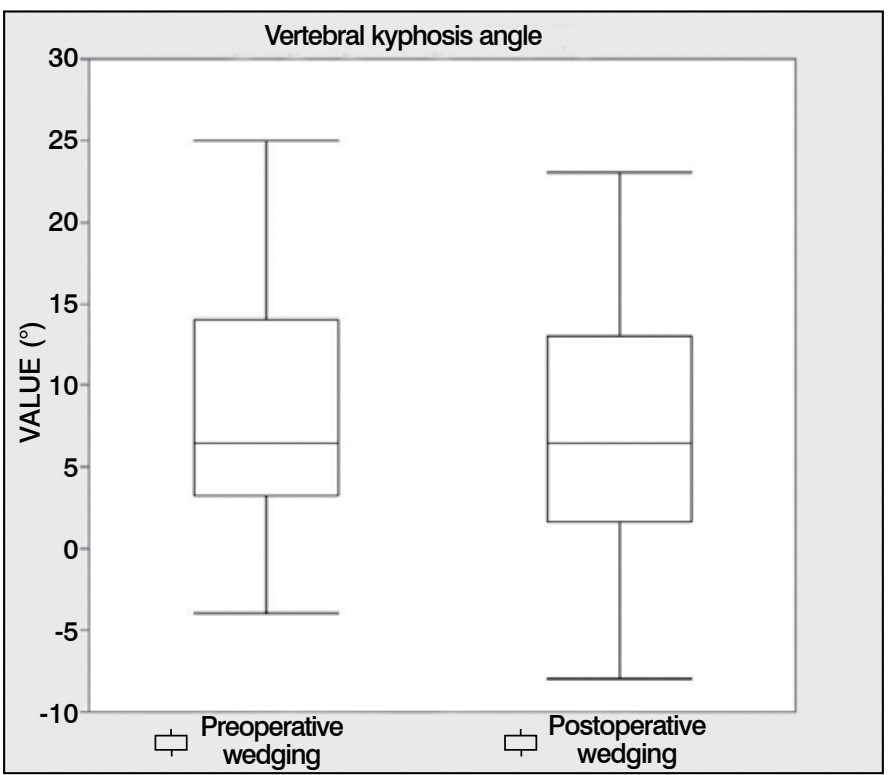

Figure 5. Vertebral wedging in pre- and postoperative periods.

literature. Dudeney et a/ ${ }^{14}$ reported pain improvement in patients with a diagnosis of vertebral fractures secondary to multiple myeloma. Another study reported the treatment of a group of 792 patients with varying diagnoses of secondary fractures and tumor lesions with good outcomes in the treatment of pain. ${ }^{14,27}$

Unlike treatment of osteoporotic fractures, restoring the height of the vertebral body is not a priority in the treatment of spinal metastases. Furthermore, it is not clear whether this characteristic is related to better treatment outcomes, and there are doubts as to whether the correction occurs due to the positioning of the patient or during the surgical procedure. ${ }^{14,16-18,20,23,28}$ It was shown that despite not having achieved correction during the procedure, short- and long-term improvement of pain was observed without any correlation with the radiographic image.

Additionally, kyphoplasty was shown to be effective and safe, with few complications in the group of patients studied. Among the complications observed, several are related to the procedure (leakage of cement and fracture of the adjacent vertebra), others to the underlying disease (stenosis of the spinal canal secondary to tumor growth, pathological fracture of the vertebra distant from the initial lesion, and the cases of death observed) and others to a combination of factors (pulmonary thromboembolism) ${ }^{29}$ Among the causes related to the procedure, we observed leakage of cement in $14.29 \%$ of the vertebrae and fracture of the adjacent vertebra in one case $(2.86 \%)$, comparable to those in the literature. ${ }^{13}$ When compared to vertebroplasty, kyphoplasty is safer during filling of the vertebral body with cement. ${ }^{10-13}$ Reviews of studies on vertebroplasty reported rates of cement leakage ranging from 2 to $67 \%$ and, when compared, the authors documented leakage rates of $9 \%$ for vertebroplasty versus $0 \%$ for kyphoplasty. ${ }^{12,13,28}$

\section{CONCLUSION}

Balloon kyphoplasty is a safe, effective, and minimally invasive procedure that offers immediate and long-term pain relief in patients diagnosed with metastasis affecting the vertebral body.

All authors declare no potential conflict of interest concerning this article.

\section{REFERÊNCIAS}

1. Lad SP, Patil CG, Lad EM, Boakye M. Trends in pathological vertebral fractures in the United States: 1993 to 2004. J Neurosurg Spine. 2007:7(3):305-10.

2. Lunt M, O'NeillTW, Felsenberg D, Reeve J, Kanis JA, Cooper C, et al. Characteristics of a prevalent vertebral deformity predict subsequent vertebral fracture: results from the European Prospective Osteoporosis Study (EPOS). Bone. 2003;33(4):505-13.

3. Borgström F, Zethraeus N, Johnell O, Lidgren L, Ponzer S, Svensson O, et al. Costs and quality of life associated with osteoporosis-related fractures in Sweden. Osteoporos Int. 2006;17(5):637-50.

4. Bouza C, López T, Palma M, Amate JM. Hospitalised osteoporotic vertebral fractures in Spain: analysis of the national hospital discharge registry. Osteoporos Int. 2007;18(5):649-57.

5. CockerillW, Lunt M, Silman AJ, Cooper C, Lips P, Bhalla AK, et al. Health-related quality of life and radiographic vertebral fracture. Osteoporos Int. 2004;15(2):113-9.

6. Papaioannou A, Kennedy CC, loannidis G, Brown JP, Pathak A, Hanley DA, et al. Determinants of health-related quality of life in women with vertebral fractures. Osteoporos Int. 2006;17(3):355-63.

7. Puffer S, Torgerson DJ, Sykes D, Brown P, Cooper C. Health care costs of women with symptomatic vertebral fractures. Bone. 2004;35(2):383-6.

8. Lieberman IH, Dudeney S, Reinhardt MK, Bell G. Initial outcome and efficacy of "kyphoplasty" in the treatment of painful osteoporotic vertebral compression fractures. Spine (Phila Pa 1976). 2001;26(14):1631-8.

9. Phillips FM, Ho E, Campbell-Hupp M, McNally T, Todd Wetzel F, Gupta P. Early radiographic and clinical results of balloon kyphoplasty for the treatment of osteoporotic vertebral compression fractures. Spine (Phila Pa 1976). 2003:28(19):2260-5.

10. Bouza C, López T, Magro A, Navalpotro L, Amate JM. Efficacy and safety of balloon kyphoplasty in the treatment of vertebral compression fractures: a systematic review. Eur Spine J. 2006;15(7):1050-67.

11. Gill JB, Kuper M, Chin PC, Zhang Y, Schutt R Jr. Comparing pain reduction following kyphoplasty and vertebroplasty for osteoporotic vertebral compression fractures. Pain Physician. 2007:10(4):583-90

12. Hulme PA, Krebs J, Ferguson SJ, Berlemann U. Vertebroplasty and kyphoplasty: a systematic review of 69 clinical studies. Spine (Phila Pa 1976). 2006;31(17):1983-2001.

13. Taylor RS, Fritzell P, Taylor RJ. Balloon kyphoplasty in the management of vertebral compression fractures: an updated systematic review and meta-analysis. Eur Spine J. 2007:16(8):1085-100.

14. Dudeney S, Lieberman IH, Reinhardt MK, Hussein M. Kyphoplasty in the treatment of osteolytic vertebral compression fractures as a result of multiple myeloma. J Clin Oncol. 2002;20(9):2382-7.

15. Fourney DR, Schomer DF, Nader R, Chlan-Fourney J, Suki D, Ahrar K, et al. Percutaneous vertebroplasty and kyphoplasty for painful vertebral body fractures in cancer patients. J Neurosurg. 2003:98(Suppl 1):21-30.
16. Gaitanis IN, Hadjipavlou AG, Katonis PG, Tzermiadianos MN, Pasku DS, Patwardhan AG. Balloon kyphoplasty for the treatment of pathological vertebral compressive fractures. Eur Spine J. 2005;14(3):250-60.

17. Grohs JG, Krepler P. Minimal-invasive stabilisierung osteoporotischer wirbelkorpereinbruche Radiologe. 2004:44(3):254-9.

18. Masala S, Lunardi P, Fiori R, Liccardo G, Massari F, Ursone A et al. Vertebroplasty and kyphoplasty in the treatment of malignant vertebral fractures. J Chemother. 2004:16(Suppl 5):30-3.

19. Masala S, Fiori R, Massari F, Simonetti G. Kyphoplasty: indications, contraindications and technique. Radiol Med. 2005;110(1-2):97-105.

20. Weisskopf M, Herlein S, Birnbaum K, Siebert C, Stanzel S, Wirtz DC. Kyphoplasty - a new minimally invasive treatment for repositioning and stabilising vertebral bodies. Z Orthop Ihre Grenzgeb. 2003;141(4):406-11.

21. Grados F, Depriester C, Cayrolle G, Hardy N, Deramond H, Fardellone P. Long-term observations of vertebral osteoporotic fractures treated by percutaneous vertebroplasty. Rheumatology. 2000;39(12):1410-4.

22. KukloTR, Polly DW, Owens BD, Zeidman SM, Chang AS, KlemmeWR. Measurement of thoracic and lumbar fracture kyphosis: evaluation of intraobserver, interobserver, and technique variability. Spine (Phila Pa 1976). 2001;26(1):61-5

23. Mendonça FP, Daher S, Daher MT, Cardoso ALP, Tristão NA, Pimenta Júnior WE, et al. Avaliação clínica e radiográfica da cifoplastia no tratamento das fraturas vertebrais por osteoporose. Coluna/Columna. 2010;9(4):381-6

24. Pflugmacher R, Taylor R, Agarwal A, Melcher I, Disch A, Haas NP, et al. Balloon kyphoplasty in the treatment of metastatic disease of the spine: a 2-year prospective evaluation. Eur Spine J. 2008;17(8):1042-8.

25. Belkoff SM, Maroney M, Fenton DC, Mathis JM. An in vitro biomechanical evaluation of bone cements used in percutaneous vertebroplasty. Bone. 1999;25(2 Suppl):23S-6S.

26. Deramond H, Wright NT, Belkoff SM. Temperature elevation caused by bone cement polymerization during vertebroplasty. Bone. 1999;25(Suppl 2):17S-21S.

27. Erdem E, Samant R, Malak SF, Culp WC, Brown A, Peterson L, et al. Vertebral augmentation in the treatment of pathologic compression fractures in 792 patients with multiple myeloma. Leukemia. 2013;27(12):2391-3.

28. Fourney DR, Schomer DF, Nader R, Chlan-Fourney J, Suki D, Ahrar K, et al. Percutaneous vertebroplasty and kyphoplasty for painful vertebral body fractures in cancer patients. J Neurosurg. 2003;98(Suppl 1):21-30.

29. Heit JA, O'Fallon WM, Petterson TM, Lohse CM, Silverstein MD, Mohr DN, et al. Relative impact of risk factors for deep vein thrombosis and pulmonary embolism: a population-based study. Arch Intern Med. 2002;162(11):1245-8. 